\title{
Characterization of Rhodnius neglectus from Two Regions of Brazil Using Isoenzymes, Genitalia Morphology and Morphometry
}

\author{
Rodrigo Pedro Pinto Soares*, Silvia Ermelinda Barbosa*, Jean-Pierre

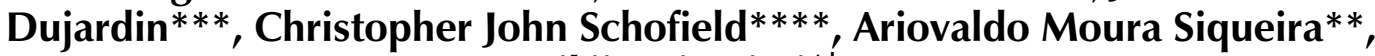 \\ Liléia Diotaiuti ${ }^{+}$
}

\begin{abstract}
Centro de Pesquisas René Rachou-Fiocruz, Av. Augusto de Lima 1715, 30190-002 Belo Horizonte, MG, Brasil *Departamento de Parasitologia **Departamento de Bioquímica e Imunologia, Universidade Federal de Minas Gerais, Av. Antônio Carlos 6627, 31270-901 Belo Horizonte, MG, Brasil ***UMR CNRS-ORSTOM 9926 "Génétique Moléculaire des Parasites et des Vecteurs", BP 5045, 34032, Montpellier cedex, France ****London School of Hygiene and Tropical Medicine, WC1 E7HT, London, UK
\end{abstract}

Among the triatomines considered as secondary in the epidemiology of Chagas disease, Rhodnius neglectus is frequently captured in artificial ecotopes, especially peridomiciliary ones, rarely producing colonies indoors. Nevertheless, the presence of breeding colonies in houses was unquestionably demonstrated in some areas of the State of Goiás, Brazil. Previous isoenzyme comparisons of this species with morphologically close triatomines, such as $R$. prolixus, $R$. robustus or $R$. nasutus, did not produce definitive conclusions because of doubt about the geographical origin of the $R$. neglectus. We present here, for the first time, the isoenzyme profile of topotypes of $R$. neglectus. In addition, wild caught specimens from the type locality, Uberaba (Minas Gerais, Brazil), were compared to wild caught specimens from Jaraguá (Goiás, Brazil), where R. neglectus is more frequently reported invading houses. We used isoenzyme, morphology and morphometry analysis. Neither morphological nor enzymatic differences were found between areas, but metric, size-related divergence was evidenced between them.

Key words: Rhodnius neglectus - isoenzyme - morphometry - genitalia - Brazil

Rhodnius neglectus Lent, 1954 is a Brazilian species of Triatominae (Hemiptera, Reduviidae) considered of secondary importance as a vector of Trypanosoma cruzi, causative agent of Chagas disease (Silveira \& Rezende 1994). It is commonly found in palm tree crowns in Central Brazil, although peridomestic colonies are increasingly reported, and domestic colonies have been found in the State of Goiás (Garcia-Zapata et al. 1985). The factors that favour domiciliation of Triatominae are poorly understood, although studies of $R$. neglectus in Goiás suggest that infestation of houses may follow environmental changes associated with changing patterns of land use (Diotaiuti et al. 1985).

Morphologically, $R$. neglectus is similar to other species of Rhodnius, especially $R$. prolixus, $R$.

\footnotetext{
This work was partially supported by CNPq, Fapemig, and PRPq of Brazil, and benefited from additional support through the ECLAT network.

${ }^{+}$Corresponding author. Fax: + 55-31-295.3115. E-mail: diotaiut@netra.cpqrr.fiocruz.br

Received 19 June 1998

Accepted 18 December 1998
}

robustus and $R$. nasutus, which are sometimes grouped with $R$. neglectus as the 'prolixus group' (Barrett 1988). R. neglectus was first separated by Lent (1954) mainly on the basis of minor differences in the male genitalia and in geographic distribution. $R$. neglectus seems confined to the savanna-like cerrado regions of Central Brazil, while $R$. nasutus occupies similar habitats in the drier caatinga of northeastern Brazil; in contrast, $R$. prolixus and $R$. robustus occur in the more humid areas of the Amazon basin northwards into Central America (Lent \& Wygodzinsky 1979, Schofield 1994). However, study of these species and definition of their geographic distribution is made difficult by their morphological similarities, and by the poorly defined origin of some laboratory colonies used for comparative purposes (Dujardin et al. 1991, WHO 1991, Harry 1993, Solano et al. 1996).

As part of a wider study on the biosystematics of Rhodnius, we report here on the morphometric, morphological and isoenzyme characterization of $R$. neglectus collected from its type locality in Minas Gerais, and from a similar locality in the neighbouring Goiás. The aim of this study was to provide isoenzymatical characterization of the spe- 
cies as well as the metric properties of the topotype specimens, and to assess the level of interpopulation variability.

\section{MATERIALS AND METHODS}

The insects - $R$. neglectus adults and nymphs were collected from two species of palm, Mauritia flexuosa (known locally as 'buriti') and Attalea speciosa (=Orbignya martiana) (babaçu) from the type locality of Fazenda Água Limpa, near the town of Uberaba, Minas Gerais, where the insects are frequently found around the houses. They were also collected from buriti palms in the municipality of Jaraguá in the neighbouring Goiás, where intradomiciliation was already reported in a recent past. In both cases, collections were made with the help of local field staff of the Fundação Nacional de Saúde, following the techniques of Diotaiuti and Dias (1984). Laboratory colonies were established from these collections, with the bugs from Uberaba (UB) and Jaraguá (JA) maintained separately in the same insectary at $27+2^{\circ} \mathrm{C}$ and $60+5 \%$ relative humidity, and fed weekly on restrained chickens. The F1 adults from these colonies were used for morphological and morphometric analysis, and electrophoresis of thoracic muscle isoenzymes was carried out on the F1 adults from UB and F2 adults from JA. The number of UB and JA founders was 15 insects (adults and nymphs from three palm trees) and 35 (adults and nymphs from 10 palm trees), respectively.

Morphometry and morphology - Morphometric measurements were taken from 10 males and 10 females from each colony. The insects had the same nutritional conditions and were not fed before morphometry. Seven measurements were taken for each specimen: TL: total body length from anteclypeus to terminalia, PL: length of pronotum,
PS: length of pronotum plus scutellum, HL: total head length (excluding neck), PO: postocular distance, AO: anteocular distance, and IO: synthlipis. All measurements were taken by the same investigator using a monocular micrometer at $10 \times 12.5$ magnification.

The same male specimens were also dissected for morphological examination of the genitalia, following the general procedure of Lent and Jurberg (1969) to examine the parameres, median process of the pygophore, phallus, phallosoma, phallosome support, phallosome process, endosome process and vesica.

Enzyme electrophoresis - Isoenzyme electrophoresis of thoracic muscle extracts from the above specimens was carried out on starch gels following the general procedures of Dujardin and Tibayrenc (1985), with enzyme staining according to Abderrazak et al. (1993). Fourteen enzyme systems were examined, as follows: alanine aminotransferase (EC 2.6.1.2., ALAT), aspartate aminotransferase (EC 2.6.1.1., ASAT), glucose-6phosphate dehydrogenase (EC 1.1.1.49., G6PD), glucose phosphate isomerase (EC 5.3.1.9., GPI), hexokinase (EC 2.7.1.1., HK), isocitrate dehydrogenase (EC 1.1.1.42., IDH), malate dehydrogenase (EC 1.1.1.37., MDH), malic enzyme (EC 1.1.1.40., ME), mannose phosphate dehydrogenase (EC 5.3.1.8., MPI), peptidase 1 (EC 3.4.11., PEP-1, substrate leucyl-leucyl-leucine), peptidase 2 (EC 3.4.13., PEP-2, substrate leucyl-L-alanine), phosphoglucomutase (EC 5.4.2.2., PGM), 6phosphogluconate dehydrogenase (EC 1.1.1.44., 6PGD) and pyruvate kinase (EC 2.7.1.40., PK).

Numerical analysis - Due to complete enzyme monomorphism and identity between samples, no detailed genetic analysis was proposed. Quantitative analysis was therefore restricted to the mor-

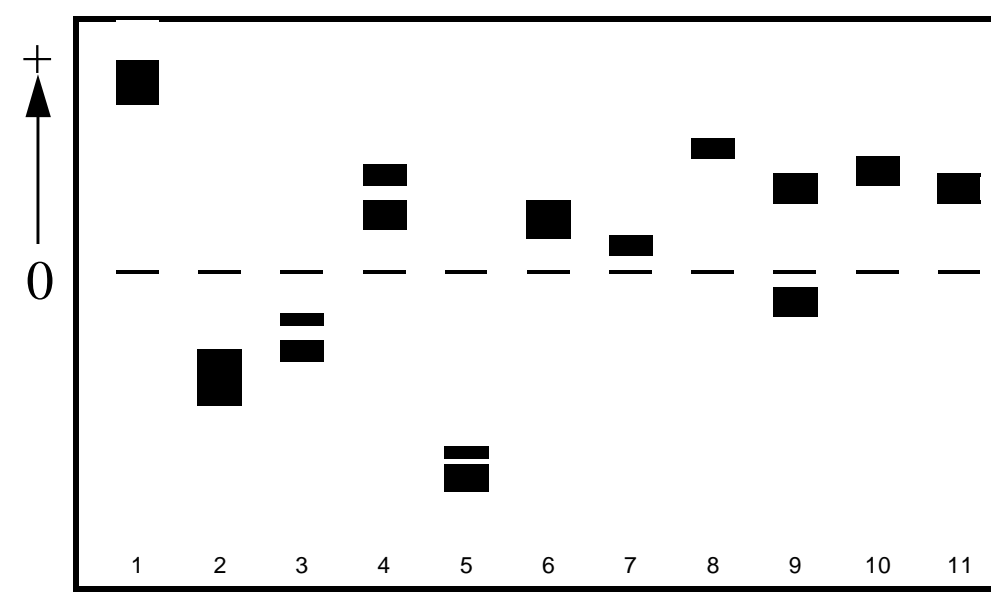

Fig. 1: electrophoretic patterns of Rhodnius neglectus from the type locality Uberaba, State of Minas Gerais, Brazil. 
TABLE I

Metric properties of the Rhodnius neglectus specimens

\begin{tabular}{|c|c|c|c|c|c|c|c|c|c|}
\hline Organ & Var & Loc & Sex & Obs & Mean & SD & Min & Max & $\mathrm{CV}$ \\
\hline \multirow[t]{16}{*}{ Head } & \multirow[t]{4}{*}{ HL } & \multirow[t]{2}{*}{ Jaraguá } & $\mathrm{F}$ & 10 & 0.59 & 0.03 & 0.52 & 0.63 & 5.63 \\
\hline & & & M & 10 & 0.54 & 0.03 & 0.48 & 0.55 & 4.77 \\
\hline & & \multirow[t]{2}{*}{ Uberaba } & $\mathrm{F}$ & 10 & 0.54 & 0.02 & 0.50 & 0.57 & 3.80 \\
\hline & & & M & 10 & 0.49 & 0.03 & 0.45 & 0.53 & 5.72 \\
\hline & \multirow[t]{4}{*}{$\mathrm{AO}$} & \multirow[t]{2}{*}{ Jaraguá } & $\mathrm{F}$ & 10 & 0.36 & 0.02 & 0.31 & 0.38 & 6.40 \\
\hline & & & M & 10 & 0.32 & 0.02 & 0.30 & 0.35 & 5.03 \\
\hline & & \multirow[t]{2}{*}{ Uberaba } & $\mathrm{F}$ & 10 & 0.32 & 0.01 & 0.30 & 0.35 & 4.63 \\
\hline & & & M & 10 & 0.29 & 0.02 & 0.25 & 0.31 & 6.41 \\
\hline & \multirow[t]{4}{*}{$\mathrm{PO}$} & \multirow[t]{2}{*}{ Jaraguá } & $\mathrm{F}$ & 10 & 0.13 & 0.01 & 0.12 & 0.15 & 8.02 \\
\hline & & & M & 10 & 0.13 & 0.01 & 0.11 & 0.15 & 8.53 \\
\hline & & \multirow[t]{2}{*}{ Uberaba } & $\mathrm{F}$ & 10 & 0.13 & 0.01 & 0.11 & 0.14 & 6.48 \\
\hline & & & M & 10 & 0.12 & 0.01 & 0.10 & 0.13 & 9.39 \\
\hline & \multirow{4}{*}{$\mathrm{IO}$} & \multirow{2}{*}{ Jaraguá } & $\mathrm{F}$ & 10 & 0.07 & 0.01 & 0.06 & 0.07 & 7.82 \\
\hline & & & M & 10 & 0.06 & 0.00 & 0.06 & 0.07 & 7.67 \\
\hline & & \multirow[t]{2}{*}{ Uberaba } & $\mathrm{F}$ & 10 & 0.06 & 0.01 & 0.05 & 0.07 & 10.20 \\
\hline & & & M & 10 & 0.06 & 0.01 & 0.05 & 0.07 & 9.62 \\
\hline \multirow[t]{8}{*}{ Thorax } & \multirow[t]{4}{*}{ PL } & \multirow[t]{2}{*}{ Jaraguá } & $\mathrm{F}$ & 10 & 0.37 & 0.03 & 0.31 & 0.41 & 8.42 \\
\hline & & & M & 10 & 0.36 & 0.02 & 0.33 & 0.39 & 5.23 \\
\hline & & \multirow[t]{2}{*}{ Uberaba } & $\mathrm{F}$ & 10 & 0.33 & 0.02 & 0.30 & 0.35 & 6.18 \\
\hline & & & M & 10 & 0.30 & 0.02 & 0.27 & 0.32 & 5.10 \\
\hline & \multirow[t]{4}{*}{ PS } & \multirow[t]{2}{*}{ Jaraguá } & $\mathrm{F}$ & 10 & 0.60 & 0.03 & 0.55 & 0.63 & 4.82 \\
\hline & & & M & 10 & 0.59 & 0.02 & 0.55 & 0.61 & 3.04 \\
\hline & & \multirow[t]{2}{*}{ Uberaba } & $\mathrm{F}$ & 10 & 0.55 & 0.03 & 0.50 & 0.60 & 5.21 \\
\hline & & & M & 10 & 0.50 & 0.02 & 0.47 & 0.55 & 4.99 \\
\hline \multirow{4}{*}{ Body } & \multirow[t]{4}{*}{ TL } & \multirow[t]{2}{*}{ Jaraguá } & $\mathrm{F}$ & 10 & 2.43 & 0.12 & 2.19 & 2.60 & 4.87 \\
\hline & & & M & 10 & 2.29 & 0.09 & 2.14 & 2.45 & 3.94 \\
\hline & & \multirow{2}{*}{ Uberaba } & $\mathrm{F}$ & 10 & 2.12 & 0.10 & 2.00 & 2.30 & 4.68 \\
\hline & & & M & 10 & 2.00 & 0.10 & 1.85 & 2.15 & 5.04 \\
\hline
\end{tabular}

HL: total head length (excluding neck); AO: anteocular distance; PO: postocular distance; IO: synthlipis; PL: length of pronotum; PS: length of pronotum plus scutellum; TL: total body length from anteclypeus to terminalia; Var: variable; Loc: locality; Obs: observations; SD: standard deviation; CV: coefficient of variation.

phometric data (Table I). Data were log-transformed for canonical variate analysis (Pimentel 1992) and the results have illustrated by plotting the centroids of each group on the first two canonical variables (Fig. 2) (Albrecht 1980). Table II summarises the corresponding discriminant classifications, with significance estimated according to Wilks (1932). All computations used JMP software (SAS Institute 1995).

\section{RESULTS}

Morphometry and morphology - Male genitalia showed no qualitative differences between samples, and presented all the features characteristic of $R$. neglectus as described by Lent and Jurberg (1969) and Lent and Wygodzinsky (1979). Only $R$. neglectus was captured in our studied areas.

By morphometry, all lengths were smaller in the Uberaba specimens, although there was greater

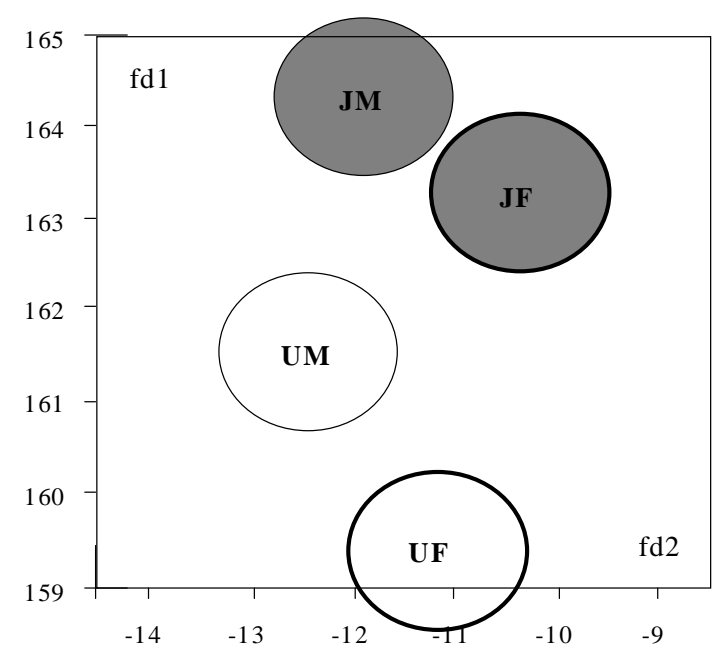

Fig. 2: canonical variate analysis of the two Rhodnius neglectus populations from Jaraguá, State of Goiás (J) and Uberaba, State of Minas Gerais (U) according to $\operatorname{sex}(\mathrm{M}=$ males and $\mathrm{F}=\mathrm{females})$. 
variability among the JA specimens. Females were also generally larger than males in both localities, and the discriminant analysis was highly significant (Pwilks $<0.0001)$ giving a substantial differentiation (Kappa $=0.77)$ between both sexes and localities (Table II, Fig. 2).

Isoenzymes - No polymorphism, nor difference in electrophoretic migration at any locus was found in comparisons of the specimens from UB and JA. In this study, we did not succeed in visualising the G6PD, 6PGD and PEP-1 enzyme systems, although other authors have shown these to be monomorphic in other samples of $R$. neglectus (Dujardin et al. 1991, Harry 1992, Solano et al. 1996). The remaining 11 enzymes each revealed a single zone of activity, except for GPI, IDH, MDH and PEP-2 which each revealed two bands, so that we could score a total of 15 loci controlling the synthesis of these systems (Fig. 1).

\section{DISCUSSION}

$R$. neglectus was first separated from other Rhodnius species by Lent (1954). Prior to that date (and in some subsequent studies) the prevailing Rhodnius species found in palm tree crowns and peridomestic habitats throughout the cerrados of central Brazil had been reported as R. prolixus, and the confusion has been repeated in many uncritically published distribution maps. But clarification of the distribution of these species is important because of their differing epidemiological significance. $R$. prolixus is the main domestic vector of T. cruzi in Venezuela, Colombia and parts of Central America, where it is subject to increasing attention as a primary target for vector control interventions (Schofield \& Dujardin 1997). In contrast, $R$. neglectus is considered a secondary vec- tor in Central Brazil, which has not achieved great epidemiological significance because of its mainly silvatic and peridomestic habits (Diotaiuti et al. 1995). Moreover, the distributional question is further confounded by the similarities with two other Rhodnius species - R. nasutus in northeastern Brazil, and $R$. robustus in the Amazon region (Schofield 1994, WHO 1991). Although in our experience the genital characteristics alone do not permit us readily to separate $R$. neglectus from other species of the 'prolixus group', they do readily distinguish $R$. neglectus from other species that might conceivably have occurred in our sample areas. In spite of it, only $R$. neglectus was captured in our studied areas.

Barrett (1988) suggested that the genus Rhodnius could be considered as a complex of species without clear-cut interspecific boundaries, and the morphological similarities between many of the species - especially of the 'prolixus group' - have certainly led to confusion in defining their geographical distribution (Dujardin et al. 1991, WHO 1991). This problem has also been exacerbated by the use of laboratory colonies, often of uncertain origin and always with the risk of contamination between different Rhodnius strains. For this reason, previous isoenzyme studies of the group have often given results that are difficult to interpret. Dujardin et al. $(1988,1991)$ could find no enzymatic difference between various samples of $R$. prolixus and samples of $R$. neglectus thought to originate from chicken coops in Goiás. Subsequently however, various $R$. prolixus strains were found to differ at four or five loci from the Fiocruz reference strain of $R$. neglectus (maintained for many years in the laboratory of the Instituto Oswaldo Cruz in Rio de Janeiro) (Dujardin 1990,

TABLE II

Canonical variate analysis of the morphometric measures CV1 81\% - CV2 14\% - P Wilks < 0.0001

\begin{tabular}{|c|c|c|c|c|c|c|}
\hline \multicolumn{7}{|c|}{ Reclassification } \\
\hline \multirow[t]{2}{*}{ Count } & & \multicolumn{2}{|c|}{ Jaraguá } & \multicolumn{2}{|c|}{ Uberaba } & \multirow[t]{2}{*}{ Predicted } \\
\hline & & Males & Females & Males & Females & \\
\hline \multirow[t]{2}{*}{ Jaraguá } & Females & 7 & 0 & 0 & 0 & 7 \\
\hline & Males & 3 & 8 & 0 & 0 & 11 \\
\hline \multirow[t]{2}{*}{ Uberaba } & Females & 0 & 0 & 9 & 1 & 12 \\
\hline & Males & 0 & 2 & 1 & 9 & 12 \\
\hline $\begin{array}{l}\text { Observed } \\
\text { Kappa }=0.77\end{array}$ & & 10 & 10 & 10 & 10 & 40 \\
\hline
\end{tabular}

Between localities, the observed agreement was $95.5 \%$ with only two individuals wrongly classified. Between sexes, the observed agreement was $87.5 \%$.The Kappa statistics measure the agreement between observed and predicted groups. It is scaled to be 0 when the agreement is as expected by chance and 1 when agreement is perfect. For intermediate values, Landis and Koch (1977) suggest the following interpretation: 0.00-0.20, slight; 0.21-0.40, fair; 0.41-0.60, moderate; 0.61-0.80, substantial. 
Dujardin et al. 1991, Solano et al. 1996) and marked isoenzyme differentiation was found by Harry (1993) between reproductively isolated strains of $R$. prolixus and $R$. neglectus from various localities.

To help resolve this problem, we present here a clearly defined isoenzyme pattern derived from topotype specimens of $R$. neglectus which may be considered as the type profile of the species. Comparison with other results (Dujardin et al. 1991, Harry 1993, Solano et al. 1996) shows that this profile will readily distinguish $R$. neglectus from other species of Rhodnius. Moreover, our study has shown complete enzyme monomorphism both in the topotype specimens and in specimens from another locality $(\mathrm{P}=0$, with $\mathrm{P}$ as the proportion of polymorphic loci). We doubt that this would be due to small sample size or genetic drift because of the number of founders collected from the field, and the small number of generations (one or two) that elapsed between our original collections and the isoenzyme analysis. Very low levels of enzyme polymorphism have been found by other authors in laboratory strains of $R$. neglectus $(\mathrm{P}=0.07$, Dujardin et al. 1991), also in wild caught $R$. pictipes ( $\mathrm{P}=0.10$ to 0.19 , Dujardin et al. 1988, Harry et al. 1992a), in R. prolixus from various sources $(\mathrm{P}=0.07$ to 0.23 , Dujardin et al. 1988, Harry 1992, Harry et al. $1992 \mathrm{a}, \mathrm{b})$ and in $R$. robustus $(\mathrm{P}=0$ to 0.16 , Harry 1992, Harry et al. 1992a, b). These and our results thus lend support to the idea of low genetic variability within the genus Rhodnius (Dujardin et al. 1998) and also suggest that the type profiles will provide a good representation of $R$. neglectus throughout its range.

In contrast to the isoenzyme results however, the morphometric analysis revealed clear differences between the two populations studied here. The UB (topotype) specimens were smaller than those from JA, although the latter showed greater variability. The two localities represent isolated populations, subsequently reared in identical insectary conditions, so that we could attribute these morphometric differences to genetic drift between the two, environmental changes, climatic and others. Reports from the National Health Foundation of Brazil have indicated a higher likelihood of finding domestic $R$. neglectus in the JA region compared to the UB region, so that it is tempting to suggest that the greater metric variability of the JA specimens may indicate greater behavioural plasticity, but this must await the results of further study.

\section{ACKNOWLEDGEMENTS}

To the staff of the Fundação Nacional de Saúde for help in collecting the insects.

\section{REFERENCES}

Abderrazak SB, Guerrini F, Mathieu-Daudé F, Truc P, Neubauer K, Lewicka K, Barnabé C, Tibayrenc M 1993. Isoenzyme electrophoresis for parasite characterization, p. 361-381. In JE Hyde, Methods in Molecular Biology, Protocols in Molecular Parasitology, Vol. 21, Hyde Co. Humana Press Inc., Totowa, NJ.

Albrecht GH 1980. Multivariate analysis of the study of form with special reference to canonical variate analysis. Amer Zool 20: 679-693.

Barrett TV 1988. Current research on Amazonian Triatominae. Mem Inst Oswaldo Cruz 83 (Suppl. I): 441-447.

Diotaiuti L, Dias JCP 1984. Ocorrência e biologia do Rhodnius neglectus, Lent 1954 em macaubeiras da periferia de Belo Horizonte-MG. Mem Inst Oswaldo Cruz 79: 293-301.

Diotaiuti L, Silveira AC, Matos CA, Elias M 1985. Estudo do Rhodnius neglectus, Lent (1954) em ecótopos silvestres do Estado de Goiás, Brasil, p. 33. XXI Congresso da Sociedade Brasileira de Medicina Tropical, São Paulo, SP.

Dujardin JP 1990. Intérêt de la Génétique des Populations dans L'étude des Vecteurs de la Trypanosomiase Américaine, $\mathrm{PhD}$ Thesis. Université de Liège, 200 pp.

Dujardin JP, Tibayrenc M 1985. Etude de 11 enzymes et données de genétique formelle pour 19 loci enzimatiques chez Triatoma infestans (Hemiptera: Reduviidae). Ann Soc Belge Med Trop 65: 271-280.

Dujardin JP, Garcia-Zapata MT, Jurberg J, Roelants P, Cardozo L, Panzera F, Dias JCP 1991. Which species of Rhodnius are invading houses in Brazil? Trans $R$ Soc Trop Med Hyg 85: 679-680.

Dujardin JP, Le Pont F, Garcia-Zapata MT, Cardozo L, Bermudez H, Tibayrenc M, Schofield CJ 1988. Rhodnius prolixus, Rhodnius neglectus, R. pictipes and Triatoma infestans: an electrophoretic comparison, p. 83. V Reunião de Pesquisa Aplicada em Doença de Chagas, Uberaba, MG.

Dujardin JP, Muñoz M, Chavez T, Ponce C, Moreno J, Schofield CJ 1998. The origin of Rhodnius prolixus in Central America. Med Vet Entomol 12: 113-115.

Garcia-Zapata MT, Virgens D, Soares VA, Bosworth A, Marsden PD 1985. House invasion by secondary triatomine species in Mambaí, Goiás-Brazil. Rev Soc Bras Med Trop 18: 199-201.

Harry M 1992. Variabílité Génétique de Population Vénézuéliennes de Rhodnius spp., Vectrices de Trypanosoma cruzi, Parasite Responsable de la Maladie de Chagas, Thesis, Paris VI, 210 pp.

Harry M 1993. Isozymic data question the specific status of blood-sucking bugs of the genus Rhodnius, vectors of Chagas' disease. Trans $R$ Soc Trop Med Hyg 87: 492.

Harry M, Galindez I, Cariou ML 1992a. Isozyme variability and the differentiation between Rhodnius prolixus strains, $R$. robustus and $R$. pictipes, vectors of Chagas' disease in Venezuela. Med Vet Entomol 6: 37-44. 
Harry M, Moreno G, Goyffon M 1992b. Genetic variability in populations of Rhodnius prolixus vector of Chagas disease in Venezuela. Evol Biológica 6: 175-194.

Landis JR, Koch GG 1977. The measurement of observer agreement for categorical data. Biometrics 33: 159174.

Lent H 1954. Comentários sobre o gênero Rhodnius Stal com descrição de uma nova espécie do Brasil (Hemiptera, Reduviidae). Rev Bras Biol 14: 237-247.

Lent H, Jurberg J 1969. O gênero Rhodnius Stal, 1859, com um estudo sobre a genitália externa (Hemiptera, Reduviidae, Triatominae). Rev Bras Biol 29: 487560.

Lent H, Wygodzinsky P 1979. Revision of the Triatominae (Hemiptera, Reduviidae), and their significance as vectors of Chagas' disease. Bull Am Mus Nat Hist 163: 125-520.

Pimentel RA 1992. An introduction to ordination, principal components analysis and discriminant analysis, p. 11-28. In RG Foottit, JT Sorensen (eds), Ordination in the Study of Morphology, Evolution and
Systematics of Insects: Applications and Quantitative Genetic Rationales, Elsevier, New York.

SAS Institute 1995. JMP, Statistics and Graphics Guide, Version 3.1, SAS Inc., Cary, NC, 593 pp.

Schofield CJ 1994. Triatominae - Biologia y Control, Eurocommunica Publications, West Sussex, UK, 80 pp.

Schofield CJ, Dujardin JP 1997. Chagas disease vector control in Central America. Parasitol Today 13: 141144.

Silveira AC, Rezende DF 1994. Epidemiologia e controle da transmissão vetorial da doença de Chagas no Brasil. Rev Soc Bras Med Trop 27 (Suppl. III): 11-22.

Solano P, Dujardin JP, Schofield CJ, Romana C, Tibayrenc M 1996. Isoenzymes as a tool for identification of Rhodnius species. Res Rev Parasitol 56: 41-47.

World Health Organization-WHO 1991. Control of Chagas Disease, Technical Report Series Control 811, Genéve, 95 pp.

Wilks SS 1932. Certain generalizations in the analysis of variance. Biometrika 24: 471. 